\title{
Can Naturalness Indicator Values Reveal Habitat Degradation? A Test of Four Methodological Approaches
}

Author(s): László Erdős, Zoltán Bátori, Károly Penksza, Andrea Dénes, Balázs Kevey, Dóra Kevey, Martin Magnes, Philipp Sengl and Csaba Tölgyesi

Source: Polish Journal of Ecology, 65(1):1-13.

Published By: Museum and Institute of Zoology, Polish Academy of Sciences

DOI: http://dx.doi.org/10.3161/15052249PJE2017.65.1.001

URL: http://www.bioone.org/doi/full/10.3161/15052249PJE2017.65.1.001

BioOne (www.bioone.org) is a nonprofit, online aggregation of core research in the biological, ecological, and environmental sciences. BioOne provides a sustainable online platform for over 170 journals and books published by nonprofit societies, associations, museums, institutions, and presses.

Your use of this PDF, the BioOne Web site, and all posted and associated content indicates your acceptance of BioOne's Terms of Use, available at www.bioone.org/page/terms_of_use.

Usage of BioOne content is strictly limited to personal, educational, and non-commercial use. Commercial inquiries or rights and permissions requests should be directed to the individual publisher as copyright holder. 


\title{
Can naturalness indicator values reveal habitat degradation? A test of four methodological approaches
}

\author{
László ERDŐS ${ }^{1,2, *}$, Zoltán BÁTORI ${ }^{3}$, Károly PENKSZA ${ }^{4}$, Andrea DÉNES ${ }^{5}$, Balázs KEVEY ${ }^{6}$, Dóra \\ KEVEY , Martin MAGNES' ${ }^{1}$, Philipp SENGL ${ }^{1}$ and Csaba TÖLGYESI ${ }^{3}$ \\ ${ }^{1}$ Institute of Plant Sciences, University of Graz, A-8010 Graz, Holteigasse 6, Austria \\ ${ }^{2}$ Institute of Ecology and Botany, MTA Centre for Ecological Research, H-2163 Vácrátót, Alkotmány utca 2-4, Hungary \\ ${ }^{3}$ Department of Ecology, University of Szeged, H-6726 Szeged, Közép fasor 52, Hungary \\ ${ }^{4}$ Department of Botany, Szent István University, H-2100 Gödöllő Páter K. u. 1, Hungary \\ ${ }^{5}$ Department of Natural History, Janus Pannonius Museum, H-7621 Pécs, Szabadság u. 2, Hungary \\ ${ }^{6}$ Department of Ecology, University of Pécs, H-7624 Pécs, Ifúság útja 6, Hungary \\ ${ }^{7}$ Medical School, University of Pécs, H-7624 Pécs, Szigeti út 12, Hungary \\ *e-mail: erdos.laszlo@okologia.mta.hu (corresponding author)
}

\begin{tabular}{|c|c|}
\hline ARTICLE INFO & ABSTRACT \\
\hline REGULAR RESEARCH PAPER & $\begin{array}{l}\text { Assessing habitat naturalness belongs to the most current issues in } \\
\text { conservation biology. It has been recognized that plants are able to }\end{array}$ \\
\hline PoL. J. ECol. (2017) 65: 1-13 & $\begin{array}{l}\text { indicate the naturalness of their habitat. Thus, species may be giv- } \\
\text { en relative naturalness indicator values (i.e. scores on an ordinal }\end{array}$ \\
\hline RECEIVED AFTER REVISION & scale), reflecting their different tolerances against habitat degrada- \\
\hline November 2016 & $\begin{array}{l}\text { tion. In the present study, our first goal was to test whether relative } \\
\text { naturalness indicator values are able to reveal known differences }\end{array}$ \\
\hline DOI & in naturalness levels. Our second purpose was to compare four dif- \\
\hline 10.3161/15052249PJE2017.65.1.001 & $\begin{array}{l}\text { ferent methodological approaches in order to identify which is the } \\
\text { most reliable when analyzing habitat naturalness. We compared } \\
\text { near-natural and degraded plots on the bases of (1) unweighted }\end{array}$ \\
\hline KEY WORDS & $\begin{array}{l}\text { plot means, (2) plot medians, (3) unweighted naturalness indica- } \\
\text { tor value populations, and (4) frequency-weighted naturalness in- }\end{array}$ \\
\hline bioindication & dicator value populations. We found that relative naturalness indi- \\
\hline naturalness & cator values performed well in differentiating among near-natural \\
\hline relative ecological indicator & and degraded vegetation. Unweighted mean indicator values were \\
\hline values & the most reliable, but frequency-weighted indicator value popula- \\
\hline Central Europe & $\begin{array}{l}\text { tions were nearly as efficient as unweighted means. We conclude } \\
\text { that relative naturalness indicator values provide a simple but reli- } \\
\text { able tool for estimating habitat deterioration. }\end{array}$ \\
\hline
\end{tabular}

\section{INTRODUCTION}

It has long been recognized that plants can be used as bioindicators to reflect certain properties of the environment (e.g. Kolkwitz and Marsson 1902, Iversen 1936, Ellenberg $1948,1950)$. The most popular, but at the same time most controversial method of making use of bioindication is the application of relative ecological indicator values, henceforth EIVs (Diekmann 2003). Species receive scores (i.e. indicator values) according to their realized ecological optima along different environmental gradients such as temperature, light, or soil moisture (Ewald 2003). Later, site conditions can be estimated on the bases of their species composition and the EIVs of the species. Several studies have shown that EIVs provide a reliable estimate of site conditions, because estimated values correlate well with the actual (instrumentally measured) values of the indicated environmental factors (e.g. Diekmann 1995, Barczi et al. 1997, Schaffers and Sýkora 2000, Dzwonko 2001). In addition, the most appropriate weighting methods and cor- 
rect statistical evaluation of these indicator values have been thoroughly explored (e.g. Käfer and Witte 2004, Zelený and Schaffers 2012, Tölgyesi et al. 2014).

Using EIVs has several advantages over instrumental measurements (Zonneveld 1983). First, environmental parameters very often fluctuate through time, which is hard to capture by instrumental measurements. In contrast, plants within a plot integrate such values over a longer period of time. Second, the application of plants as bioindicators may be less time-consuming and, perhaps more importantly, less expensive than the use of technical equipment. Third, we cannot carry out instrumental measurements in the past, but we are able to estimate earlier site conditions by using old relevés (provided that species' environmental requirements are stable over a decadal scale). Fourth, by performing instrumental measurements, the absolute values of the abiotic parameters are determined, while the importance of these values remains unknown in the context of the studied ecosystem. In contrast, the use of EIVs allows the assessment of the effects of environmental factors on the plant communities.

This latter point is related to the general indication principle, according to which populations and ecological communities are better indicators of their environment than any instrumental measurement (Juhász-Nagy 1986). Unlike technical equipment, plants do not indicate individual ecological factors separately. Rather, they indicate a number of abiotic and biotic factors at the same time. It is important to emphasize here that EIV reflect the ecological optima of the plant species, thus they provide information about the realized niches (Borhidi et al. 2000, Diekmann 2003). This, however, should by no means be considered a disadvantage: if ecologists are aware of the difference between technical measurement and bio-indication, and interpret results with care, bio-indication can be much more informative than simple measurements of selected background parameters (Bartha 2002).

Assessing habitat naturalness or degradation is among the most current issues in conservation biology, as it helps the designation of protected areas, supports management activities and contributes to an efficient monitoring of restoration projects. Naturalness is best understood as a continuum, ranging from totally altered, artificial habitats to wholly intact ones (cf. Machado 2004, Reif and Walentowski 2008, Winter 2012). Naturalness is connected to degradation in a reciprocal way: the more degraded a habitat is, the lower its naturalness is (Winter et al. 2010).

It seems clear that not only are plants able to indicate light, soil moisture, temperature and similar factors, but they also indicate naturalness/degradation in a similar way. Thus, in theory, the approach of naturalness indicator values, henceforth NIVs, is very similar to that of the EIVs. It is well-known that plant species indicate the level of degradation; some species prefer degraded sites, while others are more frequent or abundant under natural or near-natural conditions. Following this basic observation, Sukopp (1969) proposed that the preferences of plant species towards different levels of anthropogenic influences could be determined. Later, significant concentration of plant or fungi species at certain degradation levels has been statistically verified in some studies (e.g. Kowarik 1990, Wulf 1997, Kim et al. 2002, Klotz and Kühn 2002, Müller et al. 2007). Thus, species' different tolerances against degradation may be used for estimating the naturalness of a given site.

The advantages of using NIVs are similar to those of using EIVs, except for one major difference: degradation cannot be measured directly (Kowarik 1990). We may measure some parameters that are in a way related to degradation, but degradation as such cannot be measured with any technical equipment, because degradation can include several different factors, such as pollution, trampling, logging, overharvesting, fire or wetland drainage. In addition, as Zonneveld (1983) put it, "One should ask the patient herself how she is feeling." If we use NIVs, we do exactly that: we ask plant communities themselves how degraded they are.

Following this idea, Borhidi (1995) developed a system that is based partly on Grime's $(1977,1979)$ CSR-strategies and partly on Simon's (1988) naturalness categories. Borhidi (1995) assigned each vascular plant species of the Pannonian biogeographical region one "naturalness score" on an ordinal scale that ranges from -3 (plant species indicating se- 
rious degradation) to +6 (species indicating intact conditions). Species towards the lower end of the scale tend to be related to disturbed sites, while species towards the higher end tend to be concentrated in natural or nearnatural habitats. Some examples are given in Table 1.

However, NIVs do not imply that a species with a certain naturalness value occurs exclusively at a particular level of disturbance (for example, a plant with a low naturalness score may accidentally occur in quite natural habitats, although mostly with low frequency and abundancy). Rather, every habitat with a certain degradation level is expected to have a characteristic proportion of different NIV values. For example, near-natural communities are supposed to have a large number of sensitive species (with values $+4,+5$ and +6 ), while plants with lower values $(+1,+2$ and +3$)$ are less numerous, and negative values are absent or extremely rare. In contrast, low values should prevail in degraded habitats. Several studies have shown that the frequency distribution of NIVs differs among habitats that are assumed to be differently degraded (e.g. Morschhauser 1995, Török and Szitár 2010, Cseresnyés et al. 2014, Erdős et al. 2014). The most recent study was conducted in eastern Austria by Sengl et al. (2016), whose result suggests that naturalness indicator values can be used to assess the success of habitat restoration.

In spite of these promising results, NIVs need to be explored further. First, as we see it, more case studies would be necessary to test the reliability of the system, by comparing sites with different naturalness levels. Second, the performance of different statistical approaches has not been examined so far.

In this paper, our primary aim was to test if the naturalness indicator values (NIVs) of Borhidi (1995) are able to reveal known differences between near-natural and degraded plant communities. The naturalness of the study sites was estimated prior to the analyses on the basis of historical information. Our second goal was to compare four different methodological approaches, and to identify which one is the most appropriate and reliable when analyzing NIVs.

\section{STUDY AREA}

Five independent data sets were used (Fig. 1). In each data set, near-natural and degraded stands have been used for comparison. In the first and second data sets, we expected marked and obvious differences in degradation level, while the third, fourth and fifth data sets were assumed to display only moderate or minor differences.

Our first data set was from Mt Misina in the western part of the Mecsek Mts, southern Hungary (N46 $\left.5^{\prime} 43^{\prime \prime}, \mathrm{E} 18^{\circ} 13^{\prime} 8^{\prime \prime}\right)$. The mean annual temperature is $8.8^{\circ} \mathrm{C}$ and the mean annual precipitation is $723 \mathrm{~mm}$ (Szilárd 1981).

Table 1. Examples of plant species having different naturalness indicator values (NIVs).

\begin{tabular}{lll}
\hline NIV & Category name & Examples \\
\hline-3 & invasives & Asclepias syriaca, Robinia pseudo-acacia \\
-2 & ruderal competitors & Bromus sterilis, Conium maculatum \\
-1 & non-natives & Linum usitatissimum, Opuntia vulgaris \\
& (excluding invasives) & \\
1 & weeds & Galium aparine, Veronica hederifolia \\
2 & disturbance tolerants & Geum urbanum, Muscari comosum \\
3 & natural pioneers & Cerastium semidecandrum, Sedum acre \\
5 & generalists & Iris variegata, Viola reichenbachiana \\
6 & competitors & Corydalis cava, Quercus pubescens \\
\hline
\end{tabular}


The south-facing slopes of Mt Misina are usually covered by sub-Mediterranean-type plant communities (xeric oak forests, scrubs and grasslands), some of which have been replaced by non-native Pinus nigra Arn. plantations in the $20^{\text {th }}$ century. In this study, the near-natural stands were represented by xeric oak forests (Tamo-Quercetum virgilianae), while the degraded stands were plantations of $P$. nigra, which were established on previous xeric oak forests. In all other aspects, environmental conditions were very similar among the stands: they had southern expositions; the bedrock was limestone, and the soil was rusty brown forest soil in each case.

The second data set originates from Csilizköz, located next to the River Danube in southwestern Slovakia (N47 $45^{\prime} 54^{\prime \prime}$, E17 $\left.42^{\prime} 55^{\prime \prime}\right)$. The mean annual temperature is $10^{\circ} \mathrm{C}$, the mean annual precipitation is 560 $\mathrm{mm}$ (Dövényi 2010) and the soil is composed of alluvial sediments. In this region, different types of willow and poplar forests comprise the native vegetation, but presently hybrid poplar plantations occupy large areas. We compared a near-natural poplar gallery forest (Senecioni sarracenici-Populetum albae) with a Populus $\times$ euramericana (Dode) Guinier plantation.

The third data set contained a primary loess steppe near Nagylak, southeastern Hungary (N46 $\left.10^{\prime} 06^{\prime \prime}, \mathrm{E} 20^{\circ} 41^{\prime} 46^{\prime \prime}\right)$, and secondary steppe-like grasslands on the landside slope (i.e. the slope of the dike facing towards the flood-protected area) of the nearby dike of the River Maros, between Makó and Nagylak (N4612'46.7", E20²5'57.2"-N4609'19.1", E20 $\left.39^{\prime} 02.9^{\prime \prime}\right)$. The mean annual temperature is $10.6^{\circ} \mathrm{C}$ and the mean annual precipitation is $570 \mathrm{~mm}$ (Dövényi 2010). The loess steppe belongs to the association Salvio nemorosaeFestucetum rupicolae, which is the typical natural plant community of chernozem soils in Hungary. The landside slope of the dike is about 40 years old, formed after the dike reinforcement works and subsequent sowing with seed mixtures in the 1970s.

The fourth data set was from the Aigener Feld, located in the south-eastern Alpine Foreland, near the settlement Sankt Anna am Aigen, Austria (N4648'33"; E1558'59"). The mean annual temperature is $9.2^{\circ} \mathrm{C}$ and the

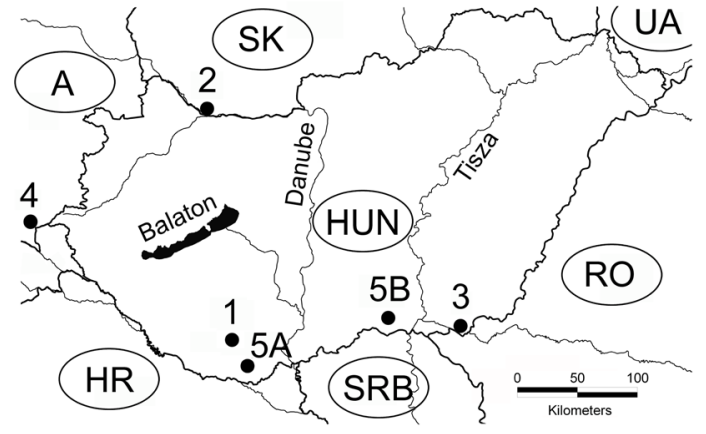

Fig. 1. Location of the study sites. 1: Mt Misina (Hungary) (data set 1), 2: Csilizköz (Slovakia) (data set 2), 3: loes steppe and dike (Hungary) (data set 3), 4: Aigener Feld (Austria) (data set 4), 5A: Mt Szársomlyó (Hungary) (data set 5, near-natural), 5B: Ásotthalom (Hungary) (data set 5, degraded).

mean annual precipitation is $835 \mathrm{~mm}$ (Zentralanstalt für Meteorologie und Geodynamik 2015). Soils are non-calcaric Cambisols with the soil type sandy loam. The region is dominated by agricultural fields, with some species-rich grassland patches (Sengl and Magnes 2008). In some sites, ecological restorations are being carried out on abandoned fields. We compared a near-natural semi-dry grassland (Cirsio pannonici-Brometum) with a neighboring regenerating grassland. Historical maps and the somewhat rugged terrain (not characteristic of arable lands) indicate that the near-natural grassland has never been ploughed, and it has been managed as a pasture and/or hay-meadow. The regenerating grassland grows at the place of a former orchard that was cleared in 2001 in the frame of a restoration project. Restoration relies totally on spontaneous immigration processes from the neighboring near-natural grassland (Sengl et al. 2015).

Our fifth data set contained two distant sites with remarkably similar land-use histories, but strongly different regeneration capabilities. We compared the forest patches of lowland and upland sub-Mediterranean forest-steppes. Both types are characterized by a mosaic of forest and grassland patches, but lowland forest-steppes occupy flat terrains, whereas upland forest-steppes cover the south-facing mountain slopes. The nearnatural state was represented by the calcareous oak scrub Inulo spiraeifoliae-Quercetum pubescentis in a nature reserve on Mt Szár- 
somlyó, southern Hungary (N48 51 '15", E1 $\left.8^{\circ} 24^{\prime} 45^{\prime \prime}\right)$, with a mean annual temperature of $10.5^{\circ} \mathrm{C}$ and a mean annual precipitation of $660 \mathrm{~mm}$ (Dövényi 2010). The bedrock is limestone and the soil is rendzina (Lehmann 1979). The degraded state was represented by the oak steppe woodland Populo canescenti-Quercetum roboris in another nature reserve, near Ásotthalom, southern Hungary (N4612'51", E19 $\left.47^{\prime} 25^{\prime \prime}\right)$, where the mean annual temperature is $10.6^{\circ} \mathrm{C}$ and the mean annual precipitation is $580 \mathrm{~mm}$ (Dövényi 2010). Vegetation grows on mostly humuspoor sandy soils of stabilized sand dunes (Bodrogközy 1982). Earlier analyses revealed that the two sites (i.e. upland and lowland forest-steppes) had remarkably similar histories: the forest component of the original foreststeppe mosaics was lacking due to grazing pressure from at least the Middle Ages till 1885 (lowland site) and the 1970s (upland site) (Erdős et al. 2013, 2015a). After grazing activities ceased, regeneration processes differed significantly. The upland site had a better regeneration potential, since forestrelated species were available on the northfacing slope, which was never grazed and was covered by forests continuously. As a result, propagule sources were only a few tens or hundreds of meters away. In contrast, there was a complete lack of forests in the whole lowland region, and even scattered trees were rare in the landscape. Thus, most of the sensitive forest-related species disappeared from the region, with poor chances for recolonization from distant propagule sources (several tens or hundreds of kilometers away). Even though grazing ended 130 years ago in the lowland site, some studies suggest that this has been too short a period for most species to recolonize (cf. Fekete et al. 2010). Thus a somewhat lower naturalness is expected in the lowland site than in the upland one, where grazing ceased later but regeneration has probably been faster.

For the first and the second data sets, the differences concerning degradation are apparent between the near-natural forests and the plantations, since the degradation is prevailing up to now in the plantations (i.e. non-native trees dominate the canopy). The case is different for the remaining data sets. In the third data set, a primary loess steppe and a secondary steppe-like grassland were compared, where the secondary grassland has developed into a steppe-like state in the last 40 years, but propagule sources were not available in the immediate vicinity. In the fourth data set, the regeneration had been going on only for 13 years when the relevés were made, but propagule sources were available within a close range. In the fifth data set, the degradation ceased a long time ago, and regeneration has been possible for several decades for both the near-natural and the degraded states, but regeneration capacities differed due to the different availability of propagule sources.

\section{MATERIAL AND METHODS}

\section{Data collection}

In each data set, we used 10 near-natural and 10 degraded relevés, resulting in a total of 100 relevés. In forests (data sets 1,2 and 5), field work was carried out from late March to April (spring aspect), and from late May to June (summer aspect). Spring and summer data were combined before the analysis. In grasslands (data sets 3 and 4), field work was done in May only. Plot sizes followed the recommendations of Lájer et al. (2007): $4 \mathrm{~m} \times 4 \mathrm{~m}$ in grasslands, and $20 \mathrm{~m} \times 20 \mathrm{~m}$ in forests, except for the oak scrubs, where $7 \mathrm{~m} \times 7 \mathrm{~m}$ plots were used, due to the small size of the vegetation patches. Presence-absence data of all vascular plant species were registered during field works. It has been shown that quantitative (abundance-weighted) indicator values usually do not produce more reliable results than qualitative ones (based on presence-absence data) (e.g. Diekmann 1995, Käfer and Witte 2004, Klaus et al. 2012).

Every effort was made to use study plots with as homogeneous a vegetation as possible to avoid erroneous results when using indicator values from heterogeneous plots (cf. Diekmann 2003). In the first and second data sets (where the canopy layers of the plantations were direct and obvious consequences of human activity), only the shrub and herb layers were analyzed, in order to avoid trivial results. In the remaining cases, all species present were included in the analyses. 


\section{Data analysis}

We used the NIVs of Borhidi (1995), which are defined for the Pannonian biogeographical region. Although our fourth data set originated from the Alpine Foreland, earlier studies have suggested that the spatial proximity to the Pannonian region, coupled with a similar species pool enable the efficient use of EIVs and NIVs defined for the Pannonian region in eastern Austria as well (Sengl et al. 2016, Willner et al. 2017). Also, the grassland association under study shows clear coenological similarities to the Pannonian region (Willner et al. 2013). Since NIVs are defined along an ordinal scale, their analysis is similar to that of EIVs. Mean EIVs (i.e. unweighted or weighted averages) are frequently used in ecology, and they seem to perform well (e.g. Dzwonko 2001, Seidling and Fischer 2008, Lengyel et al. 2012, Tölgyesi and Körmöczi 2012), even though the calculation of the mean is mathematically not correct. Instead of calculating mean values, Möller (1992) suggested that one should use medians as a statistically sound alternative. Also, instead of calculating means or medians, the raw indicator value populations may be used for statistical comparisons (e.g. Tölgyesi et al. 2014, Erdös et al. 2015b). In this case, two simple species lists are produced (one for the nearnatural, and one for the degraded state), based on all species that occurred in the relevés of the given state. In both lists, each species receives one NIV score, resulting in two sets of scores, called unweighted indicator value populations, which can be compared statistically. Also, naturalness indicator value populations can be weighted with the frequency values of the species. For example, a species that occurred in eight relevés receives eight NIV scores, while a species that occurred in only one relevé receives one NIV score. This results in two sets of scores (called frequencyweighted indicator value populations) that reflect the frequencies of the species.

In this study, NIVs were analyzed in four different ways. First, unweighted mean values were calculated for every relevé, and the nearnatural and the degraded plots were compared within each data set. Second, median values were used for the same comparisons. Third, naturalness indicator value populations were produced for both the near-natural and the degraded states, based on a simple species list for both states (without weighting). Fourth, a similar comparison was done, but naturalness indicator values were weighted with the frequency values of the species. Data were tested for normality with the Shapiro-Wilk test, and for homogeneity of variances using Levene's test. For all four methods and for all four data sets, statistical comparisons (near-natural $v s$. degraded) were done by using the MannWhitney U-test or the Brunner-Munzel test, depending on the homogeneity/heterogeneity of variances. Analyses were performed with the program packages SPSS 22.0 (IBM Corp. 2013) and ROPstat (Vargha et al. 2015). Results were visualized with barcharts.

Nomenclature follows Borhidi et al. (2012) for plant associations and Simon (2000) for plant species.

\section{RESULTS}

Naturalness indicator values (NIVs) performed well in differentiating among nearnatural and degraded vegetation.

For the xeric oak forests vs. Pinus nigra plantations, the near-natural state had higher NIVs in all cases, except the medians (Fig. 2). The naturalness of the xeric oak forests was around 4, the values of the Pinus nigra plantations were generally a bit lower. Differences were significant when using unweighted mean indicator values (Mann-Whitney $\mathrm{U}=4$, $P<0.001)$ and frequency-weighted indicator value populations (Brunner-Munzel $\mathrm{t}=5.570, P<0.001)$. With unweighted indicator value populations, naturalness of the xeric oak forests seemed to be higher than that of the Pinus nigra plantations, but the difference was not significant $(t=1.607, P=0.109)$. Medians were the same (indicator value 4) in all relevés for both the xeric oak forests and the Pinus nigra plantations.

Differences were even more pronounced between the poplar gallery forest and the Populus $\times$ euramericana plantation (Fig. 3 ). The near-natural poplar gallery forest always had higher NIVs, and differences were significant for the unweighted mean values $(\mathrm{U}=1$, $P<0.001)$, medians $(\mathrm{U}=0, P<0.001)$ and frequency-weighted indicator value popu- 


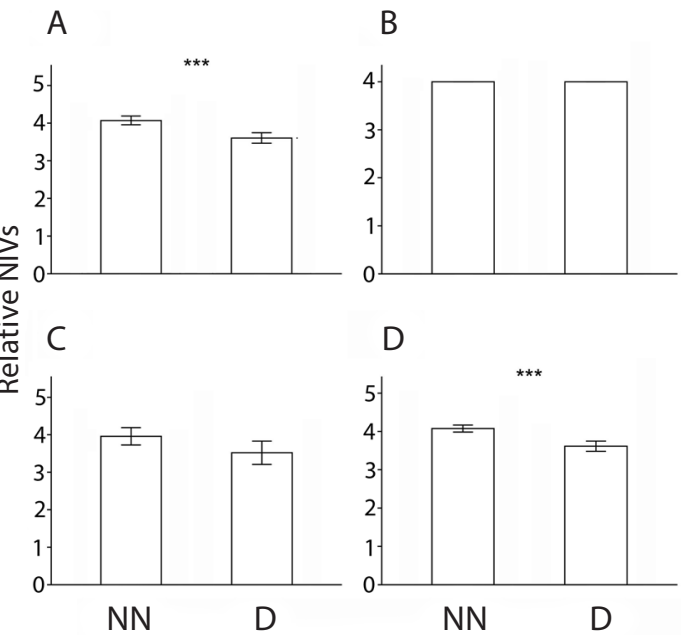

Fig. 2. Naturalness values of the near-natural (NN) xeric oak forests and the degraded (D) Pinus nigra plantations. Mean $( \pm 2 \mathrm{SE})$ indicator values are shown based on the four approaches: (A) unweighted mean indicator values, (B) median indicator values, (C) unweighted indicator value populations based on species lists, (D) frequency-weighted indicator value populations. ${ }^{* * *} P<0.001$.

lations $(\mathrm{t}=-4.595, P<0.001)$. Differences were not significant with unweighted indicator value populations $(\mathrm{U}=710, P=0.229$ ).

As for the primary loess steppe $v$ s. dike slope comparison, NIVs performed relatively poor (Fig. 4). Generally, the naturalness values of the loess steppe were low (slightly above 2 ), and hardly exceeded those of the dike slope vegetation. The primary loess steppe showed a significantly higher naturalness when unweighted mean indicator values were compared $(\mathrm{U}=23, P=0.043)$. In the case of the unweighted indicator value populations $(\mathrm{U}=2239.5, P=0.289)$ and frequency-weighted indicator value populations $(\mathrm{U}=30715$, $P=0.086$ ), the primary loess steppe reached higher values, but the differences were not significant. Medians equaled 2 in both the primary loess steppe and the dike slope.

NIVs managed to reveal the differences between the primary semi-dry grassland and the regenerating grassland using all four approaches (Fig. 5). The values of the semi-dry grassland exceeded 3, while the naturalness of the regenerating grassland was below 3. Differences were significant in all cases: unweighted mean indicator values $(\mathrm{U}=0$, $P<0.001)$, medians $(\mathrm{U}=0, P<0.001)$,

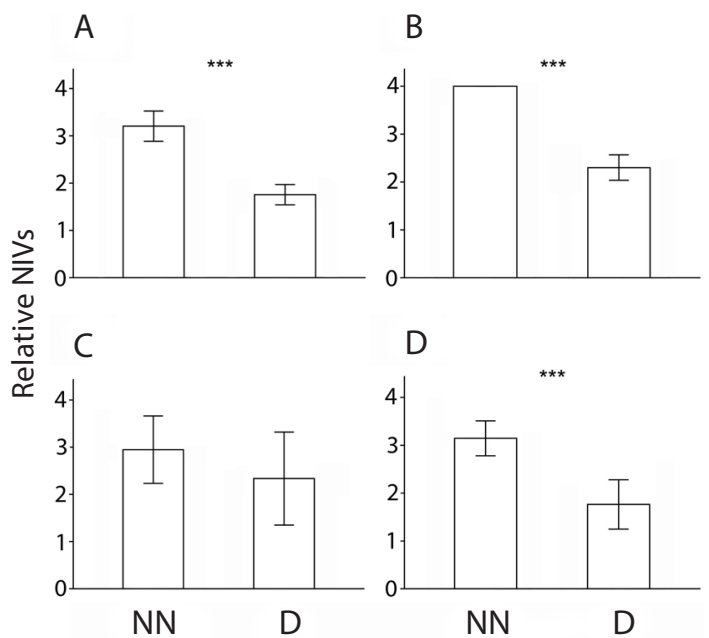

Fig. 3. Naturalness values of the near-natural (NN) poplar gallery forest and the degraded (D) Populus $\times$ euramericana plantation. Mean $( \pm 2 \mathrm{SE})$ indicator values are shown based on the four approaches: (A) unweighted mean indicator values, (B) median indicator values, (C) unweighted indicator value populations based on species lists, (D) frequency-weighted indicator value populations. ${ }^{* * *} P<0.001$.

unweighted indicator value populations $(\mathrm{U}=3978.5, P=0.001)$ and frequency-weighted indicator value populations $(\mathrm{t}=-6.096$, $P<0.001)$.
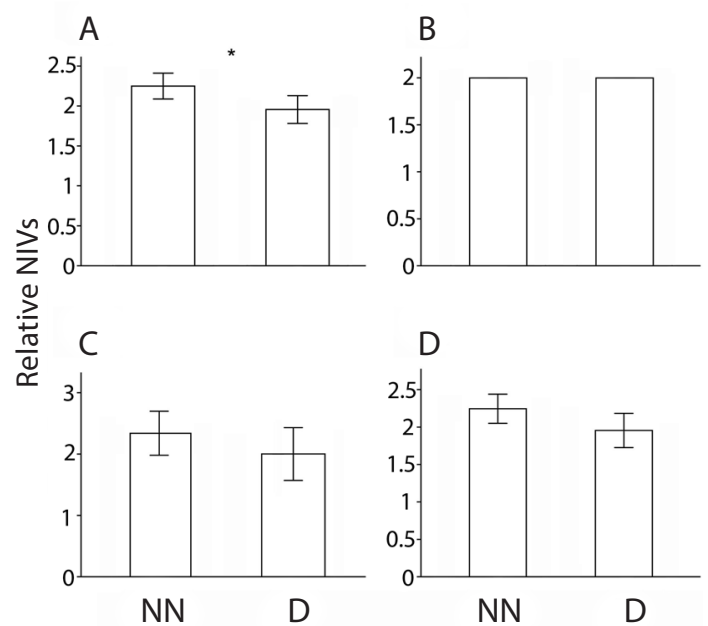

Fig. 4. Naturalness values of the near-natural (NN) primary loess steppe and the degraded (D) dike slope vegetation. Mean ( \pm 2SE) indicator values are shown based on the four approaches: (A) unweighted mean indicator values, (B) median indicator values, (C) unweighted indicator value populations based on species lists, (D) frequency-weighted indicator value populations. ${ }^{\star} P<0.05$. 


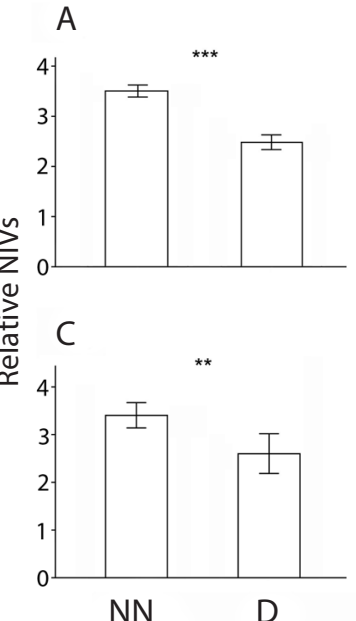

B
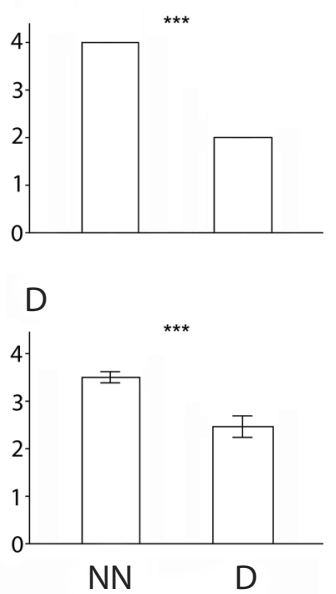

Fig. 5. Naturalness values of the near-natural (NN) semi-dry grassland and the degraded (D) regenerating grassland. Mean $( \pm 2 \mathrm{SE})$ indicator values are shown based on the four approaches: (A) unweighted mean indicator values, (B) median indicator values, (C) unweighted indicator value populations based on species lists, (D) frequency-weighted indicator value populations. ${ }^{* *} P<0.001$, ${ }^{* *} P<0.01$.

NIVs were efficient in distinguishing between the naturalness of the upland oak scrub and the lowland steppe woodland (Fig. 6). Upland oak scrub values were well above 3 , whereas lowland steppe woodlands were close to 2. Differences were significant for all four approaches: unweighted mean indicator values $(\mathrm{U}=0, P<0.001)$, medians $(\mathrm{U}=10$, $P=0.002)$, unweighted indicator value populations $(\mathrm{t}=-2.997, P=0.0031)$, frequency-weighted indicator value populations $(\mathrm{t}=-6.988, P<0.001)$.

\section{DISCUSSION}

Assessing the naturalness (or degradation) of habitats and ecosystems is among the most important tasks of conservation biology, as it supports the establishment of protected areas and helps management decisions (e.g. Angermeier 2000, Machado 2004, McRoberts et al. 2012, Winter 2012), although the best method to adequately quantify naturalness is still an open question.

According to Brūmelis et al. (2011) the degree of forest naturalness can be assessed based on community structure, species com-
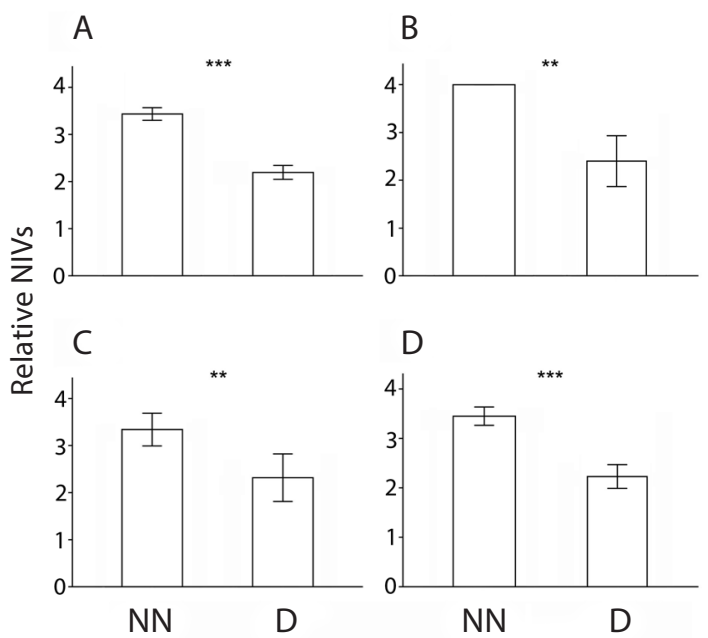

Fig. 6. Naturalness values of the near-natural (NN) upland oak scrub and the degraded (D) lowland steppe woodland. Mean $( \pm 2 \mathrm{SE})$ indicator values are shown based on the four approaches: (A) unweighted mean indicator values, (B) median indicator values, (C) unweighted indicator value populations based on species lists, (D) frequency-weighted indicator value populations. ${ }^{* *} P<0.001$, ${ }^{* *} P<0.01$.

position (including plants that specifically indicate naturalness or degradation), and ecological processes. Classification schemes developed for the quantification of the naturalness of forested or non-forested vegetation usually integrate this information in one score for the whole plant community (e.g. Dierschke 1984, Seregélyes and Csomós 1995, Parkes et al. 2003, Bölöni et al. 2008). The score of a given vegetation unit can be regarded as an indication of its position along the degradednatural continuum.

The approach of NIVs uses compositional information, since it is based on the naturalness values of the species occurring in a plot or vegetation type. Rather than selecting one or a few indicator species, this method uses the indicative power from the total species pool, which reduces error risks and increases accuracy (Zonneveld 1983, Diekmann 2003, Fränzle 2006).

Kowarik (1990) suggested that plant species should be given hemeroby indicator values (i.e. values reflecting plants' ability to tolerate human impact), and average values should be used to characterize the degradation level of plant communities, similarly to the EIVs. Kowarik (1990) also gave some basic community comparisons. 
In this article, we compared near-natural and degraded vegetation samples from five different environments, and used four different evaluation approaches to test the efficiency of the NIVs of Borhidi (1995).

Our results showed that NIVs functioned well in most cases. We found that unweighted mean indicator values were the most reliable in revealing known differences between near-natural and degraded vegetation types. Frequency-weighted indicator value populations were nearly as efficient as unweighted means. Medians and unweighted indicator populations were less efficient. The effectiveness of medians may be limited if the nearnatural and the degraded relevés are dominated by the same indicator category (e.g. category 4 in the case of the xeric oak forest vs. Pinus nigra plantation, and category 2 in the case of the loess-steppe $v s$. dike slope comparisons). Even if clear differences are present, they cannot be captured by medians. The problem with unweighted indicator value populations lies in the fact that nearnatural and even natural vegetation may contain some weedy or degradation-tolerant species in a low abundance or frequency. Also, some of the sensitive species may survive under degraded conditions, although in extremely limited numbers. Unweighted indicator values based on simple species lists are not sensitive to these differences, because both abundance and frequency values are disregarded.

According to our analysis, xeric oak forests had the highest naturalness values. Interestingly, although Pinus nigra plantations showed considerably lower naturalness, their naturalness values were relatively high compared to the other vegetation types analyzed in our study. A probable cause for this is that some of the herb layer species of the original xeric oak forests are able to survive even if the canopy layer is replaced by non-native trees (Bölöni et al. 2011). However, the marked decrease in naturalness (Fig. 2) indicates that every effort should be made to preserve these forests from being turned into non-native plantations. Moreover, Borhidi and Sánta (1999) suggest that habitat restoration activities should be started, the success chances of which may be enhanced by the survivors of the original herb layer.
Of the near-natural vegetation types examined in the present article, loess steppes had the lowest naturalness values (Fig. 4). Unfortunately, in the southeastern part of the Great Hungarian Plain, most loess steppes exist in small fragments, which has contributed to their impoverished flora and the lack of several sensitive plant species (Illyés and Bölöni 2007, Molnár et al. 2012). This is why we could identify only a minor difference between the loess steppes and the dike slope (Fig. 4). However, mean naturalness values were able to reveal significant differences, and visible (but non-significant) differences appeared with the unweighted and frequency-weighted indicator value populations (in the latter case, the difference was borderline significant).

The NIVs were efficient in revealing differences between the semi-dry grassland and the regenerating grassland (Fig. 5). It is probable that most early colonizers are disturbance-tolerant species and weeds (with some invasives), all of which have low naturalness scores. In regenerating grasslands, these plants often persist for a long time in the species-pool, and are outcompeted by near-natural vegetation only after a long period (e.g. Conrad and Tischew 2011).

Despite its apparent usefulness, NIVs should always be used with care, keeping in mind the limitations of the approach. First of all, as emphasized by Carignan and Villard (2002), the frequency of indicator species may be affected by factors unrelated to degradation. For example, plants with lower naturalness values $(+1,+2$ or +3$)$ may prevail in habitats with certain natural disturbances (considerable grazing, burrowing, strong natural erosion). This, however, should not automatically be regarded as an indication of degradation.

Second, it is important to note that the association of plant species with certain levels of degradation may vary among geographical regions. For example, a species that is limited to natural and near-natural vegetation types in one region may tolerate larger degradation elsewhere. It is possible that plants' affinity to more natural conditions increases towards their distribution limits (Hermy et al. 1999). On the other hand, the situation may be more complicated, due to rearrangements in spe- 
cies' dominance-relationships (cf. Ellenberg et al. 1992). Thus, NIVs should be used only in their region of definition and should be adjusted elsewhere if needed.

Third, NIVs are defined along an ordinal scale, which means that in a strict sense, the calculation of mean values (either weighted or unweighted averages) is not acceptable. Although Möller (1992) suggested the use of medians instead of means, we found that this is a weak alternative solution, as it was not able to reveal differences in two of the five comparisons. Mean values of EIVs are widely used, and they are usually reliable, suggesting that the mean is useful in the case of NIVs, too. Sengl et al. (2016) efficiently used frequencyweighted mean NIVs for measuring restoration success. However, if one wants to avoid mathematical problems associated with using means, they may opt for frequency-weighted indicator value populations. Not only do they allow for a statistically correct computation, but our analysis showed that they are nearly as efficient as mean values.

Fourth, NIVs may have a limited capacity to assess fine differences: if the difference is too small, random fluctuations in species composition may have a larger influence on the indicator values than habitat differences (cf. Diekmann 2003).

Last but not least, although the NIVs of Borhidi (1995) are based on extensive field works, the indicative power of individual species may need a thorough statistical evaluation and a possible refinement, based on a large number of relevés from habitats with different levels of degradation (e.g. Carignan and Villard 2002, Kim et al. 2002). Such a statistical verification was not the aim of the present paper, although our results suggest that the categorization of Borhidi (1995) appears generally valid.

\section{CONCLUSIONS}

The idea of the EIVs rests on a synthesis of a huge amount of coenological work, based on intensive field studies of more than half a century (Borhidi et al. 2000, Bartha 2002). Despite some necessary oversimplifications, the concept has proven extremely useful and efficient during the last decades. The situa- tion is similar for the NIVs, although these have been less widespread in vegetation ecology.

It seems clear that no method is perfect in measuring habitat degradation (Carignan and Villard 2002). However, our analyses suggest that the use of NIVs is a promising and powerful method, which proved to be efficient in revealing both major and moderate differences in degradation levels, in several (both forested and non-forested) environments.

In a rapidly changing world, conservation decisions usually have to be made within a limited time. Consequently, naturalness assessment must be relatively fast, but at the same time reasonably reliable (Machado 2004). As we see it, NIVs fulfill both requirements. Our results show that the approach is suitable for comparing the degradation status of different sites, and to monitor temporal changes at a given site, as suggested by Borhidi (1995). The method can be used to track habitat deterioration, check the effects of preservation or management activities, or whole restoration projects.

ACKNOWLEDGEMENTS: This work was supported by the Hungarian Eötvös Scholarship of the Hungarian Scholarship Board as well as the Research Center of Excellence 9878-3/2016/FEKUT and OTKA PD 116114 grant.

\section{REFERENCES}

Angermeier P.L. 2000 - The natural imperative for biological conservation - Conserv. Biol. 14: 373-381.

Barczi A., Penksza K., Czinkota I., Néráth M. 1997 - A study of connection between certain phytoecological indicators and soil characteristics in the case of the Tihany peninsula - Acta Bot. Hung. 40: 1-14.

Bartha S. 2002 -Describing vegetation changes with indicator values (In: Recent Hungarian botanical researches, Ed: É. Salamon-Abert) PTE Növénytani Tanszék, Pécs, pp. 527-556 (in Hungarian).

Bodrogközy Gy. 1982 - Hydroecology of the vegetation of sandy forest-steppe character in the Emlékerdő at Ásotthalom - Acta Biol. Szeged. 28: 13-39. 
Borhidi A. 1995 - Social behaviour types, the naturalness and relative ecological indicator values of the higher plants in the Hungarian flora - Acta Bot. Hung. 39: 97-181.

Borhidi A., Csete S., Csiky J., Kevey B., Morschhauser T., Salamon-Albert É. 2000 Bioindication and naturalness in plant communities (In: Vegetation and dynamics, Eds: K. Virágh, A. Kun) - MTA ÖBKI, Vácrátót, pp. 159-194 (in Hungarian).

Borhidi A., Kevey B., Lendvai G. 2012 - Plant communities of Hungary - Academic Press, Budapest, 544 pp.

Borhidi A., Sánta A. (Eds) 1999 - Red data book of the Hungarian plant communities II - TermészetBúvár Alapítvány Kiadó, Budapest, 404 pp. (in Hungarian).

Bölöni J., Molnár Zs., Horváth F., Illyés E. 2008 Naturalness-based habitat quality of the Hungarian (semi-) natural habitats - Acta Bot. Hung. 50 (Suppl.): 149-160.

Bölöni J., Molnár Zs., Kun A. (Eds) 2011 - Habitat types of Hungary - MTA ÖBKI, Vácrátót, 441 pp. (in Hungarian).

Brūmelis G., Jonsson B.G., Kouki J., Kuuluvainen T., Shorohova E. 2011 - Forest naturalness in northern Europe: perspectives on processes, structures and species diversity - Silva Fenn. 45: 807-821.

Carignan V., Villard M-A. 2002 - Selecting indicator species to monitor ecological integrity: a review - Environ. Monit. Assess. 78: 45-61.

Conrad M.K., Tischew S. 2011 - Grassland restoration in practice: Do we achieve the targets? A case study from Saxony-Anhalt/Germany Ecol. Eng. 37: 1149-1157.

Cseresnyés I., Cseresnyés-Bózsing E., Tamás J., Barina Z., Csontos P. 2014 - Effect of Austrian pine on naturalness and succession of vegetation in reclaimed bauxite quarries - App. Ecol. Environ. Res. 12: 931-946.

Diekmann M. 1995 - Use and improvement of Ellenberg's indicator values in deciduous forests of the Boreo-nemoral zone in Sweden - Ecography, 18: 178-189.

Diekmann M. 2003 - Species indicator values as an important tool in applied plant ecology: a review - Basic Appl. Ecol. 4: 493-506.

Dierschke H. 1984 - Natürlichkeitsgrade von Pflanzengesellschaften unter besonderer Berücksichtigung der Vegetation Mitteleuropas - Phytocoenologia, 12: 173-184.
Dövényi Z. (Ed) 2010 - Cadaster of the asic landscape units of Hungary - MTA FKI, Budapest, 876 pp. (in Hungarian).

Dzwonko Z. 2001 - Assessment of light and soil conditions in ancient and recent woodlands by Ellenberg indicator values - J. App. Ecol. 38: 942-951.

Ellenberg H. 1948 - Unkrautgesellschaften als Maß für den Säuregrad, die Verdichtung und andere Eigenschaften des Ackerbodens - Ber. Landtechnik, 4: 130-146.

Ellenberg H. 1950 - Landwirtschaftliche Pflanzensoziologie I. Unkrautgemeinschaften als Zeiger für Klima und Boden - Ulmer Verlag, Stuttgart, $141 \mathrm{pp}$.

Ellenberg H., Weber H E., Düll R., Wirth V., Werner W., Paulißen D. 1992 - Zeigerwerte von Pflanzen in Mitteleuropa - Scr. Geobot. 18: $1-248$.

Erdős L., Cserhalmi D., Bátori Z., Kiss T., Morschhauser T., Benyhe B., Dénes A. 2013 Shrub encroachment in a wooded-steppe mosaic: combining GIS methods with landscape historical analysis - Appl. Ecol. Environ. Res. 11: 371-384.

Erdős L., Tölgyesi Cs., Cseh V., Tolnay D., Cserhalmi D., Körmöczi L., Gellény K., Bátori Z. 2015a - Vegetation history, recent dynamics and future prospects of a Hungarian sandy forest-steppe reserve: forest-grassland relations, tree species composition and size-class distribution - Community Ecol. 16: 95-105.

Erdős L., Tölgyesi Cs., Dénes A., Darányi N., Fodor A., Bátori Z., Tolnay D. 2014 - Comparative analysis of the natural and semi-natural plant communities of Mt Nagy and other parts of the Villány Mts (south Hungary) - Thaiszia J. Bot. 24: 1-21.

Erdős L., Tölgyesi Cs., Körmöczi L., Bátori Z. 2015b - The importance of forest patches in supporting steppe-species: a case study from the Carpathian Basin - Pol. J. Ecol. 63: 213-222.

Ewald J. 2003 - The sensitivity of Ellenberg indicator values to the completeness of vegetation relevés - Basic Appl. Ecol. 4: 507-513.

Fekete G., Somodi I., Molnár Zs. 2010 - Is chorological symmetry observable within the forest steppe biome in Hungary? A demonstrative analysis of floristic data - Community Ecol. 11: $140-147$.

Fränzle O. 2006 - Complex bioindication and environmental stress assessment - Ecol. Indic. 6: 114-136. 
Grime J.P. 1977 - Evidence for the existence of three primary strategies in plants and its relevance to ecological and evolutionary theory - Am. Nat. 111: 1169-1194.

Grime J.P. 1979 - Plant strategies and vegetation processes - John Wiley and Sons, Chichester, $222 \mathrm{pp}$.

Hermy M., Honnay O., Firbank L., Grashof-Bokdam C., Lawesson J.E. 1999 - An ecological comparison between ancient and other forest plant species of Europe, and the implications for forest conservation - Biol. Conserv. 91: 9-22.

IBM Corp. 2013 - IBM SPSS Statistics for Windows, Version 22.0. - IBM Corp., Armonk.

Illyés E., Bölöni J. (Eds) 2007 - Slope steppes, loess steppes and forest steppe meadows in Hungary - Magánkiadás, Budapest, 236 pp (in Hungarian, English abstract).

Iversen J. 1936. - Biologische Pflanzentypen als Hilfsmittel in der Vegetationsforschung. Dissertation - University of Copenhagen, Copenhagen, $224 \mathrm{pp}$.

Juhász-Nagy P. 1986 - The lack of an operative ecology, its need and tasks - Akadémiai Kiadó, Budapest, 250 pp. (in Hungarian).

Käfer J., Witte J-P.M. 2004 - Cover-weighted averaging of indicator values in vegetation analyses - J. Veg. Sci. 15: 647-652.

Kim Y-M., Zerbe S., Kowarik I. 2002 - Human impact on flora and habitats in Korean rural settlements - Preslia, 74: 409-419.

Klaus V.H., Kleinebecker T., Boch S., Müller J., Socher S., Prati D., Fischer M., Hölzel N. 2012 - NIRS meets Ellenberg's indicator values: Prediction of moisture and nitrogen values of agricultural grassland vegetation by means of near-infrared spectral characteristics - Ecol. Indic. 14: 82-86.

Klotz S., Kühn I. 2002 - Indikatoren des anthropogenen Einflusses auf die Vegetation - Schriftenreihe für Vegetationskunde, 38: 241-246.

Kolkwitz R., Marsson M. 1902 - Grundsätze für die biologische Beurteilung des Wassers nach seiner Flora und Fauna - Mitt. a. d. Königl. Prüfungsanst. f. Wasserversorg. u. Abwasserbes. 1: 33-72.

Kowarik I. 1990 - Some responses of flora and vegetation to urbanization in Central Europe (In: Urban ecology. Plants and plant communities in urban environments, Eds: $\mathrm{H}$. Sukopp, S. Hejný, I. Kowarik) - SPB Academic, The Hague, pp. 45-74.
Lájer K., Botta-Dukát Z., Csiky J., Horváth F., Szmorad F., Bagi I., Dobolyi K., Hahn I., Kovács J.A., Rédei T. 2007 - Hungarian phytosociological database (COENODATREF): Sampling methodology, nomenclature and its actual stage - Ann. Bot. (Roma) 7: 27-40.

Lehmann A. 1979 - Geographical characteristics of the Villány Mts - Földrajzi Közlem. 103: 276-281 (in Hungarian).

Lengyel A., Purger D., Csiky J. 2012 - Classification of mesic grasslands and their transitions of South Transdanubia (Hungary) - Acta Bot. Croat. 71: 31-50.

Machado A. 2004 - An index of naturalness - J. Nat. Conserv. 12: 95-110.

McRoberts R.E., Winter S., Chirici G., LaPoint E. 2012 - Assessing forest naturalness - Forest Sci. 58: 294-309.

Molnár Zs., Biró M., Bartha S., Fekete G. 2012 Past trends, present state and future prospects of Hungarian forest-steppes (In: Eurasian steppes. Ecological problems and livelihoods in a changing world, Eds: M.J.A Werger, M.A van Staalduinen) - Springer, Berlin, pp 209252.

Morschhauser T. 1995 - Applications of isodegradation curves in nature conservation - Acta Bot. Hung. 39: 393-405.

Möller H. 1992 - Zur Verwendung des Medians bei Zeigerwertberechnungen nach Ellenberg - Tuexenia 12: 25-28.

Müller J., Engel H., Blaschke M. 2007 - Assemblages of wood-inhabiting fungi related to silvicultural management intensity in beech forests in southern Germany - Eur. J. For. Res. 126: 513-527.

Parkes D., Newell G., Cheal D. 2003 - Assessing the quality of native vegetation: The "habitat hectares" approach - Ecol. Manage. Restor. 4: 29-38.

Reif A., Walentowski H. 2008 - The assessment of naturalness and its role for nature conservation and forestry in Europe. - Waldökologie, Landschaftsforschung und Naturschutz, 6: 63-76.

Schaffers A.P., Sýkora K.V. 2000 - Reliability of Ellenberg indicator values for moisture, nitrogen and soil reaction: a comparison with field measurements - J. Veg. Sci. 11: 225-244.

Seidling W., Fischer R. 2008 - Deviances from expected Ellenberg indicator values for nitrogen are related to $\mathrm{N}$ throughfall deposition in forests - Ecol. Indic. 8: 639-646. 
Sengl P., Magnes M. 2008 - Halbtrockenrasen in St. Anna am Aigen (Südoststeiermark): Relikte einer gefährdeten Kulturlandschaft - Mitt. Naturwiss. Ver. Steiermark, 138: 255-286.

Sengl P., Magnes M., Wagner V., Erdős L., Berg C. 2016 - Only large and highly-connected grasslands achieve plant conservation targets in an agricultural matrix - Tuexenia, 36: 167-190.

Sengl P., Wagner V., Magnes M. 2015 - Semi-dry grassland restoration in the SE Alpine Foreland of Austria: A study of early spontaneous colonisation patterns - Hacquetia, 14: 97-112.

Seregélyes T., Csomós S.Á. 1995 - How to make vegetation maps - Tilia, 1: 158-169 (in Hungarian).

Simon T. 1988 - Naturalness categories of the Hungarian flora - Abstr. Bot. 12: 1-23 (in Hungarian).

Simon T. 2000 - Key to the vascular flora of Hungary - Nemzeti Tankönyvkiadó, Budapest, 846 pp. (in Hungarian).

Sukopp H. 1969 - Der Einfluss des Menschen auf die Vegetation - Vegetatio, 17: 360-371.

Szilárd J. 1981 - Climatic conditions (In: The Transdanubian Hills. South Transdanubia, Ed: L. Ádám, S. Marosi, J. Szilárd) - Akadémiai Kiadó, Budapest, pp. 137-169 (in Hungarian).

Tölgyesi Cs., Bátori Z., Erdős L. 2014 - Using statistical tests on relative ecological indicators to compare vegetation units - different approaches and weighting methods - Ecol. Indic. 36: 441-446.

Tölgyesi Cs., Körmöczi L. 2012 - Structural changes of a Pannonian grassland plant community in relation to the decrease of water availability - Acta Bot. Hung. 54: 413-431.

Török K., Szitár K. 2010 - Long-term changes of rock grassland communities in Hungary Community Ecol. 11: 68-76.

Vargha A., Torma B., Bergman L.R. 2015 - ROPstat: A general statistical package useful for conducting person-oriented analyses - J. Person-Oriented Res. 1: 87-98.
Willner W., Kuzemko A., Dengler J., Chytrý M., Bauer N., Becker T., Biță-Nicolae C., BottaDukát Z., Čarni A., Csiky J., Igić R., Kącki Z., Korotchenko I., Kropf M., KrstivojevićĆuk M., Krstonošić D., Rédei T., Ruprecht E., Schratt-Ehrendorfer L., Semenishchenkov Y., Stančić Z., Vashenyak Y., Vynokurov D., Janišová M. 2017 - A higher-level classification of the Pannonian and western Pontic steppe grasslands (Central and Eastern Europe) - Appl. Veg. Sci. 20: 143-158.

Willner W., Sauberer N., Staudinger M., Grass V., Kraus R., Moser D., Rötzer H., Wrbka T. 2013 - Syntaxonomic revision of the Pannonian grasslands of Austria. Part II: Vienna Woods (Wienerwald) - Tuexenia, 33: 421-458.

Winter S. 2012 - Forest naturalness assessment as a component of biodiversity monitoring and conservation management - Forestry, 85: 293-304.

Winter S., Fischer H.S., Fischer A. 2010 - Relative quantitative reference approach for naturalness assessments of forests - Forest Ecol. Manag. 259: 1624-1632.

Wulf M. 1997 - Plant species as indicators of ancient woodland in northwestern Germany - J. Veg. Sci. 8: 635-642.

Zelený D., Schaffers A.P. 2012 - Too good to be true: pitfalls of using mean Ellenberg indicator values in vegetation analyses - J. Veg. Sci. 23: 419-431.

Zentralanstalt für Meteorologie und Geodynamik 2015 - Klimadaten von Österreich 1971-2000 - URL: http://www.zamg.ac.at/ fix/klima/oe7100/klima2000/klimadaten _oesterreich_1971_frame1.htm (accessed 03.06.2015).

Zonneveld I.S. 1983 - Principles of bio-indication - Environ. Monit. Assess. 3: 207-217. 